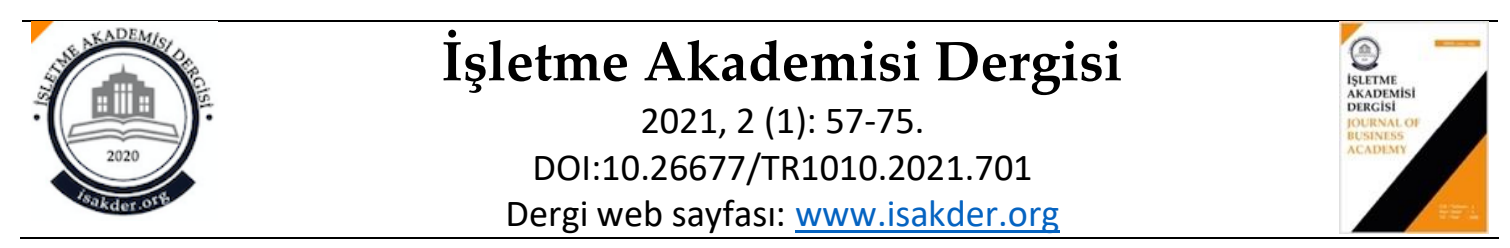

Araștırma Makalesi

\title{
Sipariş Maliyet Yöntemi: Bir Led-Line Üretim İşletmesinde Uygulama*
}

\section{Nevin TERCAN}

Yüksek Lisans Öğrencisi, Akdeniz Üniversitesi, Sosyal Bilimler Enstitüsü, Antalya, nevintercan@akdeniz.edu.tr, www.orcid.org/0000-0001-9718-1810

\section{Prof. Dr. Adnan DÖNMEZ}

Akdeniz Üniversitesi, İktisadi ve idari Bilimler Fakültesi, İşletme ABD, Antalya, adonmez@akdeniz.edu.tr, www.orcid.org/0000-0001-8632-8290

\section{Öz}

Üretim işletmelerinde mamul maliyetlerinin doğru bir şekilde hesaplanması işletmenin fiyatlama çalışmaları açısından çok büyük bir önem taşımaktadır. Doğru bir şekilde maliyet hesaplaması yapılmamış bir ürünün fiyatlamasında da yanlışlıklar ortaya çıkabilecek, belki de işletme zararına mal satmasına rağmen kar ediyormuş gibi gözükebilecektir. Bu çalışmada; led- line aydınlatma hizmeti yapan bir üretim işletmesinde kullanılan mamul maliyeti hesaplama sisteminin incelenip, işletmede sipariş maliyet sistemi oluşturularak işletmenin mevcut durumu ve sipariş maliyet sistemi kurulduktan sonraki durumunun karşılaştırılması yapılmıştır. Çalışma kapsamında; sipariş maliyeti yönteminin genel özellikleri, yöntemin aşamaları, anlatılmış ve ardından bir led-line üretim işletmesinde gerçekleştirilen uygulamanın sonuçlarına yer verilmiştir. İşletmenin sipariş maliyet sistemi kurulduktan sonra, proje maliyeti karşılaştırıldığında işletmenin maliyetleri hesaplarken doğru kararlar almadığı ve bunun sonucunda projeden zarar ettiği ortaya çıkmıştır.

* Bu çalışma Akdeniz Üniversitesi, Sosyal Bilimler Enstitüsünde sunulan "Sipariş Maliyet Sisteminin Bir Üretim İsletmesinde Uygulanması" isimli yüksek lisans tezinden türetilmiştir.

Anahtar Kelimeler: Sipariş Maliyet Yöntemi, Maliyet Muhasebesi, Maliyet Muhasebesi Sistemleri, Üretim İşletmeleri.

Makale Gönderme Tarihi: 06.01.2021

Makale Kabul Tarihi: 01.03.2021

\section{Önerilen Atıf:}

Tercan, N. ve Dönmez, A. (2021). Sipariş Maliyet Yöntemi: Bir Led-Line Üretim İşletmesinde Uygulama, İşletme Akademisi Dergisi, 2(1): 57-75.

(C) 2021 İşletme Akademisi Dergisi. 


Journal of Business Academy
$2021,2(1): 57-75$.
DOl:10.26677/TR1010.2021.701.
Web pages: www.isakder.org

Research Article

\title{
Job Order Costing Method: Implementation in A Led- Line Manufacturing Enterprise
}

\author{
Nevin TERCAN \\ Master Student, Akdeniz University, Institute of Social Sciences, Antalya, \\ nevintercan@akdeniz.edu.tr, www.orcid.org/0000-0001-9718-1810
}

\section{Prof. Dr. Adnan DÖNMEZ}

Akdeniz University, Faculty of Economics and Administrative Sciences, Department of Business Administration, Antalya, adonmez@akdeniz.edu.tr, www.orcid.org/0000-0001-8632-8290

\begin{abstract}
In the manufacturing enterprise, accurate calculation of product costs is of great importance for the pricing studies of the enterprise. Mistakes may also arise in the pricing of a product that has not been correctly calculated, and may appear to make a profit even though it sells goods at an operating loss. In this study; By examining the product cost calculation system used in a manufacturing enterprise that makes led-line lighting service, an order cost system was created in the establishment and a comparison of the current state of the enterprise and its status after the order cost system was established. Scope of work; The general features of the order cost method, the stages of the method, are described and then the result of the application carried out in ledline manufacturing enterprise are given. After the establishment's order cost system was established, when the project cost was compared, it was revealed that the enterprise did not make the right decisions when calculating the costs and as a result it was damaged by the project
\end{abstract}

Keywords: Job Order Costing Method, Cost Accounting, Cost Accounting Systems, Manufacturing Enterprises.

Received: 06.01.2021

Accepted: 01.03.2021

\section{Suggested Citation:}

Tercan, N. and Dönmez, A (2021). Job Order Costing Method: Implementation in A Led- Line Manufacturing Enterprise, Journal of Business Academy, 2(1): 57-75.

(C) 2021 Journal of Business Academy. 


\section{GİRiş}

İşletmeler ürettikleri mamul ve hizmetlerin maliyetlerini benimsemiş oldukları maliyet sisteminin kuralları dahilinde gerçekleştirmektedirler. İşletmelerin kullanacakları maliyet sistemi; maliyetlerin kapsamı, işletmenin üretim yapısı ve maliyetlerin saptandığı zamana göre dikkate alınan bir takım maliyet hesaplama yöntemlerinin bir arada kullanılmasından oluşmaktadır (Hacırüstemoğlu ve Şakrak, 2002: 19).

Maliyet muhasebesi sistemi tipik olarak iki süreci içermektedir (Horngren vd., 2002: 131)

- Maliyet Biriktirme: Maliyetler, hammadde, işçilik, gerçekleşen faaliyetler veya sipariş süreci veya makine işlem süreci olarak bazı sınıflandırmayla biriktirilmektedir.

- Maliyet Dağıtımı: Biriken maliyetin izlenmesi ve yeniden dağıtımı bir veya birden fazla maliyet nesnesine, faaliyetlere, bölümlere, tüketicilere veya ürünlere yapılmaktadır.

Sipariş maliyet yöntemini, birbirinden çok farklı mamul üreten işletmeler ve birbirinden farklı hizmetler sunan hizmet üretim işletmeleri kullanmaktadır (Yeğinboy ve Yüksel, 2015: 415). Sipariş maliyet yöntemine gereksinim duyan işletmelere; yayınevleri, inşaat işletmeleri, çeşitli mobilya, konfeksiyon ve döküm imalatı yapan işletmeler örnek olarak verilebilir (Büyükmirza, 2019: 313). Sipariş maliyet yönteminin kilit noktası, yapılan her iş ve diğer işlerin maliyetlerinin ayrı ayrı takip edilmesidir (Hansen ve Mowen, 2006: 191).

Sipariş maliyet sistemini genel olarak, müşterilerinin özel olarak talep ettikleri ürünleri üreten işletmeler kullanmaktadır. Ancak bu sistem belli bir üretim programı dahilinde üretimi gerçekleşen özellikli ürünler üreten ve bunları kısa bir süre stokladıktan sonra satan işletmeler tarafından da kullanılabilmektedir (Yükçü, 2015: 433).

$\mathrm{Bu}$ çalışmada; öncelikle sipariş maliyet yönteminin genel özellikleri, yöntemin aşamaları, yöntemde üretim maliyetleri ve üretim maliyetlerinin ürün maliyetine yüklenmesiyle ilgili açılamalara yer verildikten sonra bir led-line üretim işletmesinde gerçekleştirilen sipariş maliyet yöntemi uygulamasına ilişkin süreç açıklanmıştır.

\section{SIPARİS MALIYYT YÖNTEMI}

\subsection{Sipariş Maliyet Yönteminin Genel Özellikleri}

Sipariş maliyeti yönteminde; direkt ilk madde ve malzeme (D.I.M.M.) ile direkt işçilik (D.İ.) giderleri her bir üretim partisi için doğrudan belirlenip izlenebilirken genel üretim giderleri (G.Ü.G.) ise giderin özelliğine göre uygun bazı ölçütlerden faydalanılarak üretim partileri arasında dağıtılmaktadır (Büyükmirza, 2019: 314).

Sipariş maliyeti sisteminde siparişin maliyetinin ortaya çıarılması için muhasebe dönemi değil işin tamamlandığı süre önem taşımaktadır. Sipariş tamamlanana kadar bu sipariş için yapılan üretim maliyetleri devamlı olarak izlenecek, kayıt edilecek ve iş bittiğinde toplamı alınacaktır. Bu yöntemin bir işletmede sistem olarak işleyebilmesi için sipariş edilen her mamul veya mamul gurubuna ve bunların üretimi için yapılan giderlere ilişkin verilerin sipariş bazında bağımsız bir şekilde tutulması gerekmektedir (Akpınar ve Atiker, 2020: 337). Sipariş maliyeti sistemi, üretilen malların farklı derecelerde dikkat ve özen istediği ve bu sebeple de farklı iş partileri halinde birbirinden ayrılabildiği sanayi dallarında uygulanmaktadır. Bu tür sanayi kollarına örnek olarak makine sanayii, uçak sanayii, mobilya sanayii, inşaat sanayii, matbaacılık gösterilebilir (Gürsoy, 2009: 173). 
Sipariş maliyeti yönteminde; direkt ilk madde ve malzeme giderleri, direkt işçilik giderleri ve genel üretim giderleri üretim tamamlanıncaya kadar sipariş maliyeti kartlarında biriktirilmekte ve üretimin tamamlanması ile de üretilen mamul ya da mamullere yüklenmektedir. Her parti üretim için maliyetler ayrı bir sipariş kartında izlenmektedir (Yereli vd., 2015: 440). Fakat burada dikkat edilmesi gereken direkt ilk madde ve malzeme giderleri ve direkt işçilik giderlerinin ne şekilde hesaplanacağı ve genel üretim giderlerin hangi yükleme ve dağıtım yöntemleri ile mamul maliyetlerine yükleneceğinin saptanmasıdır. Durum şematik olarak Şekil 1'de gösterilmiştir:

\section{D.İ.M.M. Giderleri}

\section{(Kullanılan Miktar x Birim Maliyet)}

Stok Değerleme Yöntemine Göre Belirlenecektir.

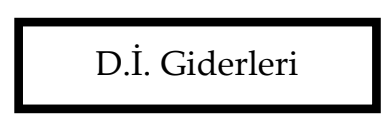

\section{2}

(Kullanılan Zaman x Birim Saat Ücreti)

Ücretlendirme sistemlerine göre belirlenecektir.

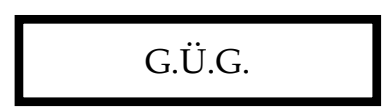

3

SİPARIŞ MALİYETI

$=1+2+3$

Dağıtım Yöntemlerine göre belirlenecektir.

Şekil 1. Sipariş Maliyet Yönteminin İşleyişi (Kaynak: Altuğ, 2006: 292)

\subsection{Sipariş Maliyet Yönteminin Aşamaları}

Maliyetlerin siparişlere dağıtımı birbirini izleyen yedi aşamalı bir yaklaşımla gerçekleştirilmektedir. Bu yaklaşım çoğunlukla, üretim işletmeleri, ticaret işletmeleri ve hizmet sektörü tarafından da benimsenmektedir (Horngren vd., 2009: 127). Sipariş maliyet yönteminin uygulamasına ilişkin adımlar aşağıda açıklanmıştır:

1. Aşama: İlk olarak üretimine başlanan her mamul veya mamul grubu için bir sipariş numarası verilerek o sipariş için bir sipariş maliyet kartı açıı.ı. Sipariş maliyet yönteminin uygulanmasında kaynak doküman, sipariş maliyet kartıdır. Sipariş maliyet kartı, üretime başlanıldığında açıır ve yapılan işle ilgili bütün maliyetler gider yerleri itibariyle ayı ayrı izlenir ve sipariş maliyeti kartına kaydedilir (Kaygusuz ve Dokur, 2018: 262). Sipariş maliyet kartında en azından; kartın ait olduğu üretim partisine ait iş emri numarası, partiyi oluşturan ürün miktarı, partinin üretimine başlama ve bitiş tarihi, üretim partisi ile ilişkili direkt ilk madde ve malzeme, direkt işçilik ve genel üretim giderlerinin gösterileceği alanların yer alması gerekir (Büyükmirza, 2019: 319).

2. Aşama: Bu aşamada siparişle ilgili direkt giderler belirlenir. Üretim maliyetini oluşturan direkt giderler; direkt ilk madde ve malzeme giderleri ve direkt işçilik giderleridir. Siparişin üretiminde 
kullanılan direkt ilk madde ve malzemenin içeriği hakkında bilgi veren kaynak doküman ilk madde ve malzeme istek fişidir. Sipariş için kullanılan hammaddenin çeşidi, miktarı, birim maliyet ve toplam maliyeti bilgilerinin yer aldığı bu belgede yer alan bilgiler ait olduğu üretim partisine ait sipariş maliyet kartına işlenir. Direkt işçilik giderlerinin tespitinde ise kullanılan kaynak belge, işçilik zaman kartı özetidir. Bu belgede sipariş için yapılan direkt işçilik ile ilgili kayıtlar yer almaktadır. Bu karttan elde edilen bilgiler ait oldukları siparişlerin sipariş maliyet kartına işlenir (Akdoğan, 2009: 435-436; Büyükmirza, 2019: 319). Siparişle ilgili makine bakım onarım ve makinelerin temizliği gibi diğer işçilik maliyetleri direkt işçilik gideri kabul edilmemektedir. Örneğin, siparişi oluşturan mamul veya mamul gruplarının üretimi için 25 direkt işçilik saati çalışılmış ve makinelerin bakım onarımı ve temizliği içinde 3 saat çalışılmış ise 3 saatlik bakım onarım işçiliği endirekt iş̧̧iliktir ve direkt gider olarak siparişe yüklenmeyecektir. Bu tür giderler genel üretim gideri olarak dikkate alınırlar ve dağıtım yoluyla sipariş maliyetine yüklenirler.

3. Aşama: Bu aşamada siparişe ilişkin endirekt giderler belirlenir. Endirekt giderler tek bir maliyet havuzunda biriktirilir. Bu giderler genel üretim gideri olarak adlandırılmaktadır. Bu havuz siparişe direkt yüklenemeyen üretimle ilgili tüm endirekt giderleri temsil etmektedir. Endirekt giderler fiili tutarlar üzerinden yüklenebildiği gibi tahmini (götürü) yükleme oranı kullanılarak yüklenmesi yoluna da gidilebilmektedir. Genel üretim gideri olarak kabul edilen bazı giderlerin yıl içerisinde düzensiz dağılması ve bazılarının kesinleşmiş tutarlarının yıl sonunda ortaya çıkması gibi nedenler maliyet hesaplamalarında gecikme ve hatalı hesaplamaya yol açabilmektedir. Bu nedenle uygulamada bazı işletmeler genel üretim giderlerini her yılın başında tahmine dayalı olarak maliyetlere yüklemekte ve dönem sonunda fiili tutarlar ile karşılaştırma yaparak gerekli düzeltmeleri yapma yolunu tercih etmektedirler (Yükçü, 2015: 231232; Büyükmirza, 2019: 338-339).

4. Aşama: $\mathrm{Bu}$ aşamada endirekt giderlerin dağıtım anahtarları (yükleme ölçüsü) belirlenir. İşletmeler, endirekt giderlerin dağıtımında birden çok dağıtım anahtarı kullanır, çünkü farklı endirekt maliyetlerin farklı maliyet faktörleri vardır. Örneğin, amortisman ve makine tamiratı ile ilgili genel üretim giderleri makine işçilik saati ile daha alakalı iken gözetim ve üretim destekleri gibi gider unsurları daha çok direkt işçilik saatiyle ilgilidir. Doğru bir hesaplama için sipariş için yapılan direkt işçilik ve endirekt işçiliğin çok iyi ölçülmesi gerekmektedir.

5. Aşama: $\mathrm{Bu}$ aşamada siparişe ilişkin endirekt giderlerin dağıtım oranı (yükleme oranı) hesaplanır. Siparişle ilgili endirekt maliyetlere ilişkin yükleme oranları direkt ilk madde ve malzeme giderleri, direkt işçilik giderleri, bakım onarım saati vb. gibi farklı dağıtım anahtarlarından yararlanılarak hesaplanabilmektedir (Yükçü, 2015: 229-231; Büyükmirza 2019: 315). Dağıtım oranının hesaplanması aşağıda bir örnek yardımı ile açıklanmaya çalışılacaktır (Horngren vd., 2009: 131).

Robinson Company, ilgili dönem için genel üretim giderleri toplamını \$ 1.215 .000 ve yine ilgili dönem için çalışılan direk iş̧̧ilik saatini 27.000 saat olarak saptamıştır. İşletme genel üretim giderlerinin dağıtımında dağıtım anahtarı olarak direkt işçilik saatini kullanmaktadır. Bu bilgiler ışığında genel üretim giderleri dağıtım oranı aşağıdaki gibi hesaplanmıştır: 
Fiili Genel Üretim Giderleri Toplam Tutarı

Genel Üretim Gideri Dağıtım Oranı :

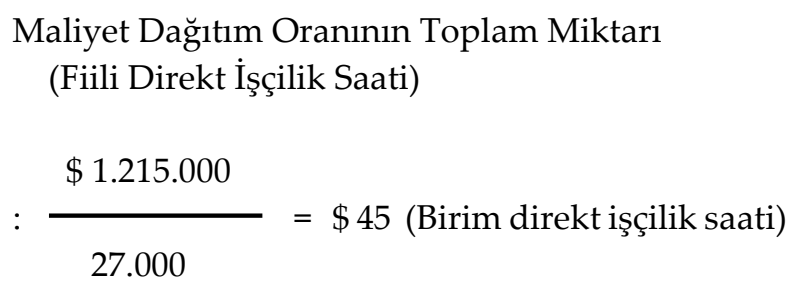

6. Aşama: Bu aşamada endirekt giderlerin üretilen mamul veya mamul gruplarına yüklenmesi gerçekleştirilir. Burada yüklenecek tutar hesaplanır iken daha önce hesaplanan dağıtım oranı ile ilgili mamule ait dağıtım anahtarı değeri çarpılır (Büyükmirza, 2019: 333).

Yukarıda dağıtım oranı hesaplanan Robinson Company'nin ilgili sipariş için belirlenen direkt işçilik saatinin 88 saat olduğu varsayımı ile sipariş için belirlenen endirekt gider (genel üretim gideri) toplamı aşağıdaki gibi hesaplanacaktır (Horngren vd., 2009: 131):

Siparişe Yüklenen Genel Üretim Gideri: $\quad \$ 45$ X 88 direkt işçilik saati= \$3,96

7. Aşama: Son aşama olan bu aşamada daha önceki adımlarda elde edilen bilgilerden yararlanılarak siparişe ait toplam maliyet hesaplanır. Bu aşama daha önceki iki aşamada yararlanılan örnek yardımı açıklanmaya çalışılacaktır.

Robinson Company'nin ilgili sipariş için direkt ilk madde ve malzeme giderlerini \$ 4.606 ve direkt işçilik giderlerini de \$ 1.579 olarak hesapladığı varsayımı ile siparişe ait toplam maliyet aşağıdaki gibi hesaplanacaktır:

Direkt Üretim Giderleri

Direkt İlk Madde ve Malzeme

Direkt İşçilik

Genel Üretim Giderleri

(\$45 G.ÜG oranı X 88 saat)

Siparişin Toplam Maliyeti
$\$ 6.185$

$\$ 4.606$

$\$ 1.579$

\subsection{Sipariş Maliyet Yönteminde Üretim Maliyetleri ve Mamul Maliyetlerine Yüklenmesi}

Üretim maliyetleri direkt ilk madde ve malzeme ve direk işçilik giderleri toplamından oluşan direkt giderler ile genel üretim giderleri olarak nitelendirilen endirekt giderlerden oluşmaktadır.

Direkt ilk madde ve malzemenin maliyeti, direkt olarak mamule yüklenebilmektedir, çünkü üretimde kullanılan direkt malzeme miktarı fiziki olarak gözlemlenebilir ve ölçülebilirdir. Hammadde, mamulün somut bir kısmıdır ve direkt ilk madde ve malzeme olarak sınıflandırılır. Örneğin, otomobilde kullanılan çelik, mobilyanın odunu, kolonyadaki alkol, kot pantolonun kumaşı, dişleri düzeltmek için diş teli, cerrahi operasyon için gazlı bez ve anestezi, hava yolu yolcuğunda verilen yemek bunların hepsi direkt ilk madde ve malzemedir (Hansen ve Mowen, 2006: 40). 
Direkt işçilik giderlerinin izlenmesinde işçi çalışma kartlarından yararlanılmaktadır. Bu giderler ortaya çıktıkça, ilk madde malzeme istek fişlerine ve işçi çalışma kartlarına dayanılarak ilgili siparişin maliyet kartlarına yazılır (Karakaya, 2011: 333).

Genel üretim giderleri ise; üretimi ilgilendiren ancak direkt ilk madde ve malzeme ve direkt işçilik giderleri gibi mamul maliyetleri ile doğrudan bağlantısı kurulamayan diğer tüm giderler olarak tanımlanmaktadır. Bu grupta izlenecek giderlerin mutlaka üretim ile ilişkisinin olması gerekmektedir, üretim ile ilişkisi kurulamayan giderler gelir tablosunda dönem gideri olarak izlenmelidir. Örneğin üretim ile ilgili makine ve tesisatın amortisman giderleri üretim maliyetinin bir unsuru olarak genel üretim gideri kabul edilirken, pazarlama departmanında kullanılan taşıtlara ait amortisman giderleri pazarlama satış ve dağıtım gideri olarak kabul edilmektedir (Yükçü, 2015: 221).

Genel üretim giderleri enerji giderleri, amortisman giderleri, kira giderleri, endirekt işçilik giderleri gibi mamul maliyeti ile doğrudan bağlantısı kurulamayan çok sayıda gider türünden oluşmaktadır. Bu gider türlerinin bir bölümü sabit (değişmez), bir bölümü ise değişken giderlerdir. Örneğin, amortisman giderleri sabit gider iken enerji giderleri değişken giderdir (Kaygusuz ve Dokur, 201: 162). Genel üretim giderleri ile mamuller arasında çoğu zaman doğrudan bir ilişki kurulması çok mümkün olmadığı için genel üretim giderlerinin mamul maliyetine yüklenmesinde çeşitli dağıtım yöntemlerinden yararlanılır. Genel üretim giderlerinin bir bölümü zaman içerisinde düzensiz seyir gösterir. Bazı aylar az, bazı aylar fazla tutarda gerçekleşir. Örneğin, yakacak maliyetleri, işçi ikramiyeleri gibi. Bu düzensiz dağılımları nedeniyle bu tür genel üretim giderleri bütçeler yardımıyla mamul maliyetine yüklenirler. Yine bazı genel üretim giderlerinin toplam tutarları yıl sonunda kesinleştiği için (bakım onarım giderleri ve yemekhane giderleri gibi) fiili maliyet yaklaşımı kullanıldığında kesin maliyetler ancak yıl sonunda hesaplanabilmekte ve bu durum maliyet hesaplamalarında gecikmeye neden olmaktadır. Gecikmeden kaynaklı olumsuzlukların önüne geçmek içinde işletmeler bu tür genel üretim giderlerini mamul maliyetine yüklerken tahmini maliyet yaklaşımını kullanmaktadırlar (Yükçü, 2015: 226-227).

Direkt ilk madde ve direkt işçilik giderleri mamullere ve hizmetlere kolayca dağıtılmaktadır. Ancak genel üretim giderleri mamullere doğrudan yüklenememesinden dolayı uygun dağıtım ölçüsü veya anahtarı kullanılarak dağıtıma tabi tutulmaktadır. Genel üretim giderlerinin dağıtımı birbirini takip eden ve birinci dağıtım, ikinci dağıtım ve üçüncü dağıtım olarak adlandırılan üç aşamadan oluşan bir süreç ile gerçekleştirilir (Kaygusuz ve Dokur, 2018: 166).

Birinci dağıtım, üretim ile ilişkili olarak ortaya çıkan endirekt nitelikteki gider türlerinin (gider çeşitleri) uygun dağıtım anahtarları ile gider yerlerine dağıtılması işleminden oluşmaktadır (Büyükmirza, 2019: 265).

Birinci dağııımın işleminin hemen sonrasında ikinci dağıtım işlemi gerçekleştirilir. İkinci dağıtım, yardımcı üretim gider yerleri ile hizmet gider yerleri giderlerinin, bu gider yerlerinin üretiminden ve hizmetinden yararlanan gider yerleri arasında dağıtılması işlemidir (Akdoğan, 2009: 365):

Üçüncü dağıtım ise birinci ve ikinci dağıtım işlemleri sonrasında esas üretim gider yerlerinde toplanan giderlerin bu gider yerlerinde üretilen birimlere (mamul ve/ veya hizmetlere) yüklenmesi işlemi olarak tanımlanmaktadır (Lazol, 2011: 115).

Yukarıda açıkladığımız tüm gider unsurların toplu olarak yer aldığı ve sipariş maliyet yöntemini destekleyen temel belge sipariş maliyet kartıdır. Bu kart her siparişin, direkt madde malzeme, direkt işçilik ve genel üretim giderlerini kaydedip özetlemektedir. Üretim süreci başladığında sipariş maliyet kartı açılır. Sipariş maliyet kartında, hammadde, işçilik ve genel üretim giderleri 
için alanlar vardır. Üretim süreci boyunca maliyet akışları sipariş maliyet kartına kaydedilir. Üretim tamamlanınca genel üretim giderleri belirli bir oranla maliyetlere eklenir. Sipariş maliyet kartının toplam tutarı siparişin tutarını oluşturmaktadır. Her birimin ortalama maliyeti, birim sayısına bölünerek birim sipariş maliyeti hesaplanmaktadır (Blocher vd., 2005: 96).

Aşağıda Şekil 2'de üretim maliyetlerinin unsurları sunulmuştur.

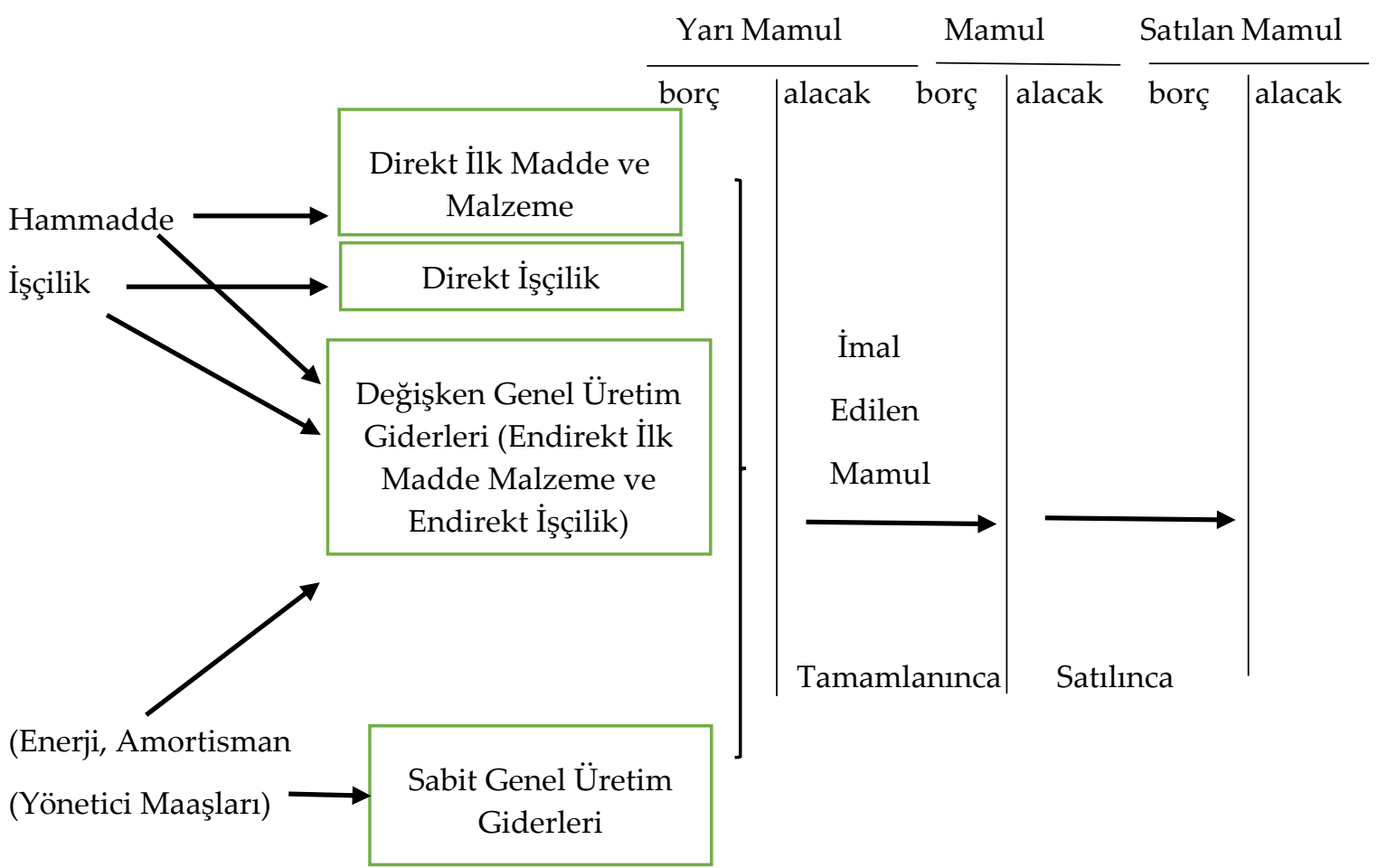

Şekil 2. Sipariş Maliyet Yönteminde Üretim Maliyetleri ve Siparişlere Yüklenmesi

(Kaynak: Raiborn ve Kinney, 2011:39)

\section{SIPPARIŞ MALIYYT YÖNTEMININ LED-LİNE ÜRETIM İŞLETMESİNDE UYGULANMASI}

\section{1.İşletme Hakkında Bilgiler}

Uygulamanın yapıldığı örnek işletme, Türkiye' de ve dünyada birçok müşterisine dış mekan iç mekan ve ofis aydınlatması, havuz, peyzaj zemin aydınlatması, elektronik sistemler, fiber optik aydınlatma sistemleri kurmaktadır. Çok farklı alanlarda mühendislik hizmeti üreten işletme, 1991 yılında kurulmuş ve ses-görüntü sşık uygulamalarıyla başlayıp, 2000 yılında bu alandan çekilip Led ve Fiber Optik sistemde uzmanlaşmaya yönelmiştir. Antalya organize sanayi bölgesinde bulunan ve $6000 \mathrm{~m} 2$ 'lik kapalı alana sahip olan işletme 20'den fazla ülkeye çağdaş aydınlatma hizmeti sunmaktadır. Ayrıca, İstanbul, Ankara, İzmir, Rusya ve Türkmenistan'da şubeleri bulunmaktadır. Asıl üretim merkezi Antalya olup, 265'den fazla çalışanıyla faaliyetini sürdürmektedir 


\subsection{Led-line Üretim İşletmesinde Sipariş Maliyet Yönteminin Uygulanması}

Sipariş maliyet yöntemi uygulamasının ilk başlama noktası işletmedeki tüm gider yerlerini tespit etmek ve gider yerlerini bölümlemektir. Bundan sonraki aşamada ise sipariş için oluşturulan İş Emirleri ve İlk Madde ve Malzeme İstek Fişlerinden, Direkt ilk madde ve malzeme giderlerini tespit etmektir. İşçi çalışma kartı özetlerinden üretim için gerçekleştirilen Direkt İşçilik giderlerini tespit etmektir. Sipariş süresince oluşan Genel Üretim Giderleri ise belirli bir oran üzerinden maliyetlere dağıtımı planlanmaktadır. Çünkü örnek işletmenin, birden fazla proje üretimi ve birden fazla şubesi olduğundan genel üretim giderleri oldukça fazladır. Örnek uygulanın gerçekleştirilmesi aşamasında işletmenin 2015 yılı Mart, Nisan ve Mayıs ayı bilgilerinden yararlanılmıştır.

\subsubsection{Led-Line Üretim İşletmesinin Gider Yerlerinin Tespiti ve Bölümlendirilmesi}

Uygulamaya konu olan işletmenin gider yeri bölümlemeleri aşağıda gösterilmiştir. 3 adet esas üretim gider yeri (E.Ü.G.Y.), 1 adet yardımcı üretim gider yeri (Y.Ü.G.Y.), 5 adet yardımcı hizmet gider yeri (Y.H.G.Y.) ve 2 adet üretim yerleri yönetimi gider yeri (Ü.Y.Y.G.Y.) bulunmaktadır.

\section{ÜRETIM GIDER YERLERİ}

Esas Üretim Gider Yerleri

- Dizgi Bölümü (2 kişi)

-Mekanik Bölümü (2 kişi)

-Montaj Bölümü (2 kişi)

Yardımcı Üretim Gider Yeri

- Stadyuma Yerinde Montaj Ekibi (10 kişi)

Yardımo Hizmet Gider Yerleri

- Kalite Kontrol (1 kişi)

- Paketleme (1 kişi)

- Sevkiyat (1 kişi)

-Yemekhane (1 kişi)

- Personel servis hizmeti (1 kişi)

Üretim Yerleri Yönetimi Giderleri

- Üretim -Planlama Bölümü (2 kişi)

- Teknik Şeflik (1 kişi)

\section{DÖNEM GIDER YERLERİ}

- Araştırma ve Geliştirme Gider Yeri

- Pazarlama- Satış Dağıtım Gider Yeri

- Genel Yönetim Gider Yeri

- Finansman Gider Yeri

\subsubsection{Led-Line Üretim İşletmesinin Üretim Maliyetlerinin Tespiti}

Çalışmada, sipariş usulü alınan Stadyum projesinin Led Line aydınlatması yapılmıştır. Üretimplanlama ekibi tarafından, imalat için gerekli malzemenin hesaplanması yapılmış ve hammadde tedarik süreci gerçekleştirilmiştir. Planlama ekibi tarafından oluşturulan iş emirleri ilgili operasyonların yapılması için üretim birimlerine gönderilmiştir. Her ürüne ait ilk madde 
malzemelerin maliyet bilgisi, işletmenin finansman ve üretim- planlama bölümü ile yapılan görüşme sonucu mevcut veri tabanından elde edilmiştir. Üretim bölümü tarafından oluşturulan 4 adet Illk Madde ve Malzeme İstek Fişinin toplamı, Direkt İlk Madde Malzeme maliyetini oluşturmaktadır. Stadyum Led-Line aydınlatması için toplam 9.142,6 metre Led- Line kullanılmıştır.

1- 02.03.2015 tarihli 87 nolu İlk Madde Malzeme İstek Fişi

2- 16.03.2015 tarihli 109 nolu İlk Madde Malzeme İstek Fişi

3- 06.04.2015 tarihli 138 nolu İlk Madde Malzeme İstek Fişi

4- 20.04.2015 tarihli 162 nolu İlk Madde Malzeme İstek Fişi
$77.980,63$ €

96.808,23

$171.511,54 €$

$+\quad 80.216,51 €$

TOPLAM: $\quad 426.516,91 €$

Aşağıda Tablo 1'de Led-Line üretim işletmesinin direkt ilk madde ve malzeme giderlerinin detayına yer verilmiştir.

Tablo 1. Led-Line Üretim İşletmesinin Direkt İlk Madde ve Malzemenin Maliyetlerinin Tespiti

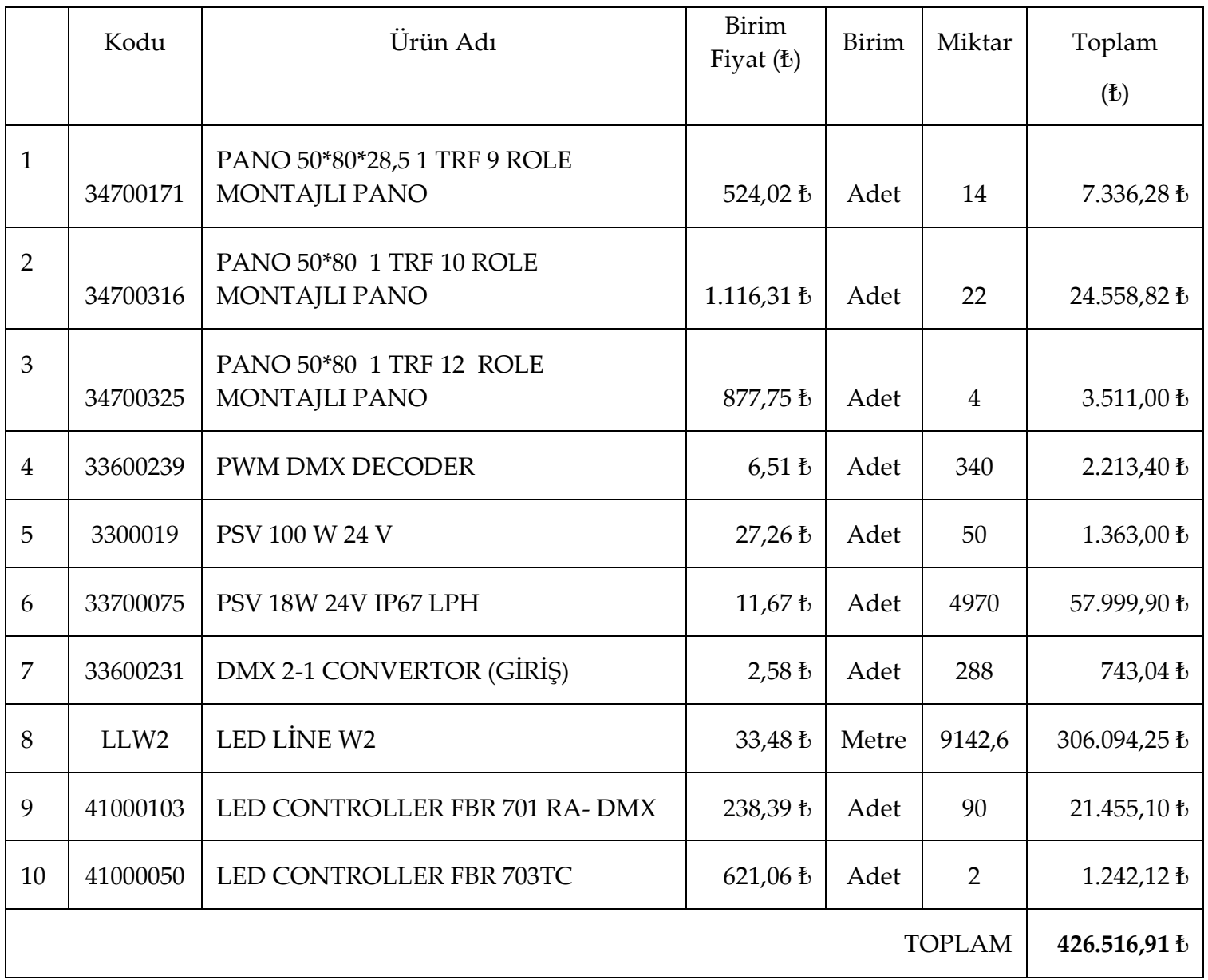

$$
\text { Birim Led- Line Maliyeti }=\frac{\text { Toplam Maliyet }}{\text { Toplam Metre }}=\frac{426.516,91 \mathrm{f}}{9142,6 \mathrm{Mt}}=46,65159911 \mathrm{\ddagger} / \mathrm{Metre}
$$


Led line üretimi iş̧̧iliği iki aşamada olmaktadır. İlk aşamada fabrikada üretimi yapılmakta sonra stadyuma yerinde montajı yapılmaktadır. Fabrikada çalışan işçiler projeyi, Mart ayında 5, Nisan ayında 4, Mayıs ayında 5 gün hafta tatili yaparak gerçekleştirmişlerdir. Haftalık çalışma süresi 45 saat aylık 180 saattir. İşçilik giderleri zaman esasına göre hesaplanmaktadır. İşletme ücrete tabi çalışma saatlerini ay içerisinde çalışılan gün sayısına bölmekte ve bulduğu günlük ücrete göre de ayrıca tatil ücretlerini tahakkuk ettirmektedir. İşletmede vardiya sistemi ve fazla çalışma bulunmamaktadır. Led-Line üretim işletmesinin EÜ.G.Y.'ne ait işçilik maliyetleri Tablo 2'de sunulmuştur.

Tablo 2. Led-Line Üretim İşletmesinin Esas Üretim Gider Yerleri Toplam İşçilik Maliyetleri

\begin{tabular}{|l|l|l|l|l|c|c|c|c|c|}
\hline Ay & $\begin{array}{l}\text { Çalış. } \\
\text { Süre } \\
\text { Saat }\end{array}$ & $\begin{array}{l}\text { Normal } \\
\text { Ücret } \\
(£)\end{array}$ & $\begin{array}{l}\text { Hafta } \\
\text { Tatili } \\
\text { Ücreti } \\
(£)\end{array}$ & $\begin{array}{l}\text { Sosyal } \\
\text { Yardım }\end{array}$ & $\begin{array}{c}\text { Brüt } \\
\text { Ücret } \\
(£)\end{array}$ & $\begin{array}{c}\text { Dizgi } \\
(£)\end{array}$ & $\begin{array}{c}\text { Mekanik } \\
(£)\end{array}$ & $\begin{array}{c}\text { Montaj } \\
(£)\end{array}$ & $\begin{array}{c}\text { Toplam } \\
(£)\end{array}$ \\
\hline Mart & 1.080 & 11.900 & $2.288,46$ & 6.000 & $20.188,46$ & $6.292,31$ & $7.365,38$ & $6.530,77$ & $20.188,08 €$ \\
\hline Nisan & 1.080 & 11.900 & $1.830,77$ & - & $13.730,77$ & $4.153,85$ & $5.192,31$ & $4.384,62$ & $13.730,77 £$ \\
\hline Mayıs & 1.080 & 11.900 & $2.288,46$ & - & $14.188,46$ & $4.292,3$ & $5.365,39$ & $4.530,77$ & $14.188,46 £$ \\
\hline Toplam & 3.240 & 35.700 & $6.407,69$ & 6.000 & $48.107,69$ & $14.738,46$ & $17.923,08$ & $15.446,16$ & $48.107,31 £$ \\
\hline
\end{tabular}

\begin{tabular}{|c|c|c|c|c|}
\hline \multirow[b]{2}{*}{ Direkt İşçilik Giderleri } & DİZGİ & \multirow{2}{*}{$\begin{array}{l}\text { MEKANIK } \\
15.862,5 €\end{array}$} & MONTAJ & \multirow{2}{*}{$\begin{array}{c}\text { TOPLAM } \\
41.947,50 €\end{array}$} \\
\hline & 12.690 き & & $13.395 €$ & \\
\hline \multirow[t]{2}{*}{ Endirekt İşçilik Giderleri } & $4.627,68 €$ & $5.197,13 €$ & $4.754,22$ € & $\underline{14.579,03}$ \\
\hline & \multicolumn{3}{|c|}{ Esas Üretim İşçilik Giderleri Toplamı = } & $56.526,53$ छ \\
\hline \multicolumn{5}{|c|}{ DİREKT İŞÇILİK GIDERLERİ } \\
\hline Esas Ücretler $\quad$ (saat üc & \multicolumn{3}{|c|}{ (saat ücreti x 3240 saat) } & $35.700 €$ \\
\hline SSK İşveren & \multicolumn{3}{|c|}{$\% 15,50$} & $=5.533,50 €$ \\
\hline \multicolumn{4}{|c|}{ İşsizlik Sigortası \% 2} & $=$ \\
\hline \multicolumn{4}{|c|}{ Siparişin Direkt İşçilik Gideri } & $=41.947,50 €$ \\
\hline \multicolumn{5}{|c|}{ ENDİREKT İŞÇİLIKK GIDERLERİ } \\
\hline \multicolumn{5}{|c|}{ Üretici İşçiliklere Ait Endirekt İşçilikler: } \\
\hline \multicolumn{4}{|l|}{ Hafta sonu Tatili Ücreti } & $=6.407,69 €$ \\
\hline \multicolumn{4}{|l|}{ Sosyal Yardimlar } & $=\underline{6.000} €$ \\
\hline SSK İssveren & & & & $=\frac{12.407,69}{1.923,19 €}$ \\
\hline \multicolumn{4}{|c|}{ İşsizlik Sigortası \%2 $(12.855,34$ x 0,02) } & $=248,15 €$ \\
\hline & Endirekt İ & Gideri & & $=14.579,03$ \\
\hline
\end{tabular}

SSK İşveren işsizlik primi brüt ücretin \% 2'sidir. SSK işveren primi işyerinde yapılan işin tehlike derecesine göre değişiklik gösterir. İş sağlığı ve güvenliği kanununa göre insan hayatını tehlikeye atan işlerdeki prim dereceleri farklılık göstermektedir. SSK işveren primi brüt ücretin \% 15,50' si alınmıştır. İşletmede ödenen sosyal yardımların tamamı SSK işveren ve işveren işsizlik 
sigortasına tabidir. Bu kesintilerin hesaplanması, işletmenin İnsan Kaynakları bölümünden alınan veriler ve yapılan açıklamalar ışığında hazırlanmıştır.

İşletme dışındaki yardımcı üretim gider yeri ise stadyuma montaj ekibidir. 10 adet personel fabrikada hazırlanan Led- lineların stadyuma yerinde montaj işlemini yapmışlardır. İşletmede, kalite kontrol, paketleme, sevkiyat, yemekhane, personel servis hizmeti, yardımcı hizmet gider yeri bulunmakta ve 5 adet personel çalışmaktadır. Üretim yerleri yönetiminde 2 adet mühendis ve 1 adet teknik şef bulunmaktadır.

$$
\begin{array}{ll}
\text { Yardımcı Üretim Gider Yeri -Stadyum Montaj Ekibi İşçilik Maliyeti (Mayıs Ayı) } \\
\begin{array}{ll}
\text { Kişi Sayısı } & 10 \\
\text { Brüt Ücret } & =36.368,10 €(3.636,81 \times 10 \text { kişi }) \\
\text { SSK İşveren }(\% 15,50) & =5.637,05 € \\
\text { İşsizlik işveren ( \% 2) } & =727,36 € \\
\text { İşverene Toplam Maliyeti } & =\mathbf{4 2 . 7 3 2 , 5 1}
\end{array}
\end{array}
$$

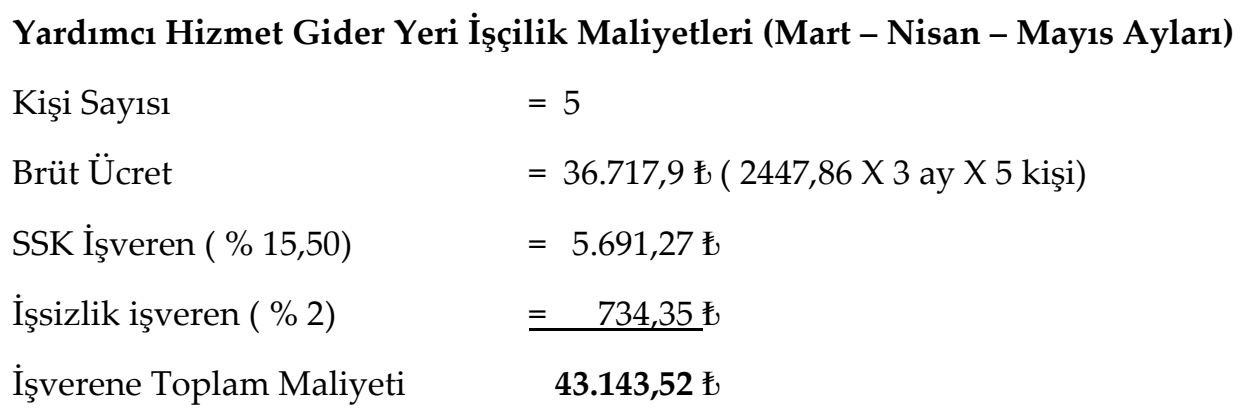

\section{Üretim Yerleri Yönetimi İşçilik Maliyetleri (Mart- Nisan- Mayıs)}

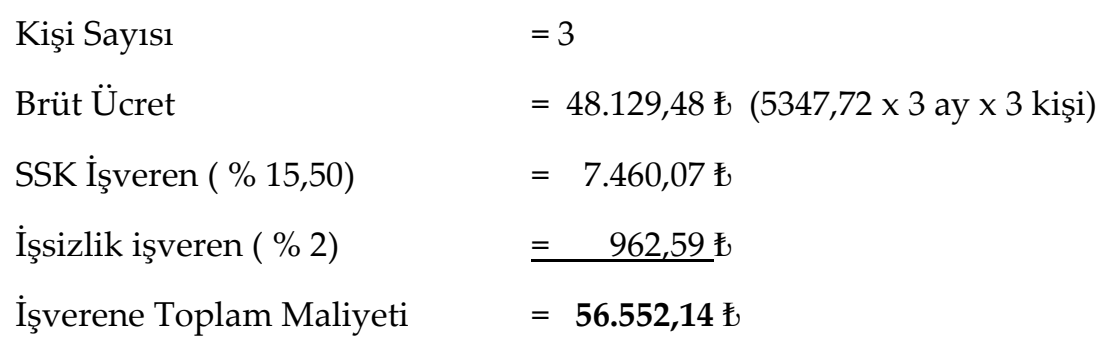

\subsubsection{Led-Line Üretim İşletmesinin Genel Üretim Giderlerinin Tespiti ve Dağıtılması}

Sipariş maliyet sistemi, ürünlerin genel üretim maliyetlerini yükleme oranları ile mamul maliyetine yüklemektedir. Uygulamanın yapıldığı işletmede, yardımcı hizmet gider yeri ve üretim yerleri yönetimi gider yeri maliyetleri genel üretim gideri olarak iki grupta incelenmiştir. Dönem gideri olarak, ar-ge, satı̧s- pazarlama ve genel yönetim gideri incelenmiştir.

Üretimle ilgili gider türleri, dışardan sağlanan fayda ve hizmet, çeşitli gider, vergi resim harçlar, amortismanlar, yemek gideri, personel yol giderleri ve yükleme oranları aşağıda açıklanmıştır. 
Stadyum montaj ekibi fabrika dışında çalışma yaptığı için bazı hesaplamalarda hariç bırakılmış, bu bölümün kendi harcamaları gider dağıtım tablosuna dahil edilmiştir. Birinci dağıtıma konu olan gider türleri, dağıtım anahtarları ve yükleme oranı hesaplamaları aşağıda verilmiştir:

\section{Gider Türleri}

(Mart, Nisan, Mayıs Ayları Toplamı)

Endirekt İşçilik

Dışardan Sağ.Fay.Hiz.= 67.100,77 €

Çeşitli Gider $\quad=3.860,01 £$

Vergi Resim Harç $\quad=2.903,67$ €

Amortismanlar $\quad=49.360 €$

\section{Dağıtım Anahtarı}

Her bölümün gerçekleşen işçilik maliyeti

Gider yerlerine eşit

Gider yerlerine eşit

Gider yerlerine eşit

Her bölümün kendi amortisman payı

Yemek Gideri $=67.192,7$ £ $150=$ 447,95 € x Kişi sayısı (Stadyum Montaj ekibi hariç)

Personel Yol Gideri $=97.742,86$ € /150 = 651,61 € x Kişi sayısı (Stadyum Montaj ekibi hariç)

Stadyum Ekibi Yemek Gid. = 1.493,16 £ (Mayıs)

Stadyum Ekibi Yol Gid. $\quad=2.279,41 €($ Mayıs)

Led-Line üretim işletmesinin I.dağıtım işlemine ait bilgiler aşağıda Tablo $3^{\prime}$ te verilmiştir.

Tablo 3. Gider Dağıtım Tablosu (Birinci Dağıtım)

\begin{tabular}{|c|c|c|c|c|c|}
\hline GIDERLER & E.Ü.G.Y. & Y.Ü.G.Y. & Y.H.G.Y. & Ü.Y.Y.G.Y. & TOPLAM \\
\hline $\begin{array}{l}\text { Direkt İlk Madde } \\
\text { Malzeme Gider. }\end{array}$ & $426.516,91$ £ & - & - & - & $426.516,91$ £ \\
\hline Direkt İşçilik & $41.947,50$ છ & - & - & & $41.947,50$ € \\
\hline $\begin{array}{l}\text { MAMUL DİREKT } \\
\text { GIDER TOPLAMI }\end{array}$ & $468.464,41$ b & - & - & - & $468.464,41 \mathrm{E}$ \\
\hline Endirekt İşçilik & $14.579,03$ モ & $42.732,51$ モ & $43.143,52$ £ & $56.552,14 €$ & $157.007,20 €$ \\
\hline $\begin{array}{l}\text { Dişardan sağlanan } \\
\text { fayda hizmet }\end{array}$ & $18.300,21$ モ & $6.100,07$ € & $30.500,35$ € & $12.200,14$ € & $67.100,77 €$ \\
\hline Çeşitli Gider & $1.052,73 €$ & $350,91 €$ & $1.754,55 €$ & 701,82 € & $3.860,01 €$ \\
\hline Vergi Resim Harç & 791,91 £ & $263,97 €$ & $1.319,85 €$ & 527,94 € & $2.903,67 €$ \\
\hline Amortismanlar & $36.600 €$ & $2.150 €$ & $7.750 €$ & $2.860 €$ & $49.360 £$ \\
\hline Yemek gideri & 2.687,70€ & $1.493,16 €$ & $2.239,75 €$ & $1.343,85 €$ & $7.764,46 £$ \\
\hline Personel Yol gideri & $3.909,69 €$ & $2.279,41 €$ & $3.258,05 €$ & $1.954,84$ € & $11.401,99 €$ \\
\hline $\begin{array}{l}\text { Mamul Endirekt } \\
\text { Gider Toplamı }\end{array}$ & $77.921,27$ ఏ & $55.370,03$ E & $89.966,07$ t & $76.140,73$ E & $299.398,10 \mathrm{E}$ \\
\hline $\begin{array}{l}\text { I DAĞITIM } \\
\text { TOPLAMI }\end{array}$ & $546.385,68 \mathrm{E}$ & $55.370,03$ E & $89.966,07$ f & $76.140,73$ E & $767.862,51 \mathrm{E}$ \\
\hline
\end{tabular}

Yardımcı hizmet gider yerleri ve üretim yerleri yönetimi gider yerlerinde oluşan giderlerin dağıtımında, kademeli dağıtım yöntemi kullanılmıştır. Gider yerleri arasındaki hizmet ilişkisi eşit olduğundan, dağıtıma en yüksek gider yerinden (üretim-planlama) başlanarak yapılmıştır. Kademeli dağıtımda her bölüm kendisinden sonraki bölüme pay vermektedir. Dağıtım anahtarı olarak çalışan işçi sayısı kullanılmıştır. Fakat, yardımcı üretim gider yeri olan stadyum montaj ekibinin gideri, dağıtımdan ayrı tutulmuştur. Ayrı tutulmasının nedeni bu bölümün diğer hizmet yerleriyle arasında hizmet ilişkisi bulunmamaktadır. Led-Line üretim işletmesinin ikinci dağıtım işlemine ait bilgiler aşağıda Tablo 4 'te verilmiştir. 
Tablo 4. Gider Dağıtım Tablosu (İkinci Dağıtım)

\begin{tabular}{|c|c|c|c|c|c|}
\hline GİDERLER & E.Ü.G.Y. & Y.Ü.G.Y. & Y.H.G.Y. & Ü.Y.Y.G.Y. & TOPLAM \\
\hline $\begin{array}{l}\text { I DAĞITIM } \\
\text { TOPLAMI }\end{array}$ & $546.385,68$ モ & $55.370,03$ છ & $89.966,07 \varsubsetneqq$ & $76.140,73 €$ & $767.862,51 €$ \\
\hline $\begin{array}{l}\text { Ü.Y.Y.G.Y. } \\
\text { dağıtımı }\end{array}$ & $41.531,31$ € & - & $34.609,42 £$ & $-76.140,73 €$ & \\
\hline $\begin{array}{l}\text { Y.H.G.Y. } \\
\text { dağıtımı }\end{array}$ & $124.575,49$ き & - & $-124.575,49 £$ & & \\
\hline $\begin{array}{l}\text { Y.Ü.G.Y. } \\
\text { dağıtımı }\end{array}$ & $55.370,03$ € & $-55.370,03 €$ & & & \\
\hline $\begin{array}{l}\text { TOPLAM } \\
\text { MALIYET }\end{array}$ & $767.862,51$ છ & & & & \\
\hline
\end{tabular}

3.2.4.İşletmenin Stadyum Projesi Sipariş Maliyet Kartının Oluşturulması ve Birim Ürün Maliyetinin Hesaplanması

Led-Line üretim işletmesinin sipariş maliyet kartının oluşturulması aşamasında önce yukarıda bu kartın oluşturulmasına esas teşkil edecek tüm hesaplamalar gerçekleştirilmişti. Yukarıda yapılan D.İ.M.M. gideri, direkt işçilik gideri ve genel üretim giderlerine ait hesaplamalar sonrasında işletmenin stadyum projesine ilişkin düzenlenen sipariş maliyet kartı aşağıda Tablo 5 'te sunulmuştur.

Tablo 5. Stadyum Projesi Sipariş Maliyeti Kartı

\begin{tabular}{|c|c|c|c|c|c|}
\hline \multirow{3}{*}{\multicolumn{3}{|c|}{$\begin{array}{l}\text { Sipariş No: } 7376 \text { Stadyum Projesi } \\
\text { Mamulün Türü : Led-line } \\
\text { Siparişin Miktarı: 9142,6 mt }\end{array}$}} & \multicolumn{3}{|c|}{ Siparişin Üretime Alınma Tarihi: $\quad$ 01.03.2015 } \\
\hline & & & & \multicolumn{2}{|c|}{ Üretim Bitiş Tarihi: 31.05 .2015} \\
\hline & & & MALIYYET KA & TTI & \\
\hline $\begin{array}{l}\text { Gider } \\
\text { Yerleri }\end{array}$ & $\begin{array}{l}\text { Direkt İlk } \\
\text { Madde Gid. }\end{array}$ & $\begin{array}{l}\text { Gider } \\
\text { Yerleri }\end{array}$ & $\begin{array}{l}\text { Direkt } \\
\text { İşçilik Gid. }\end{array}$ & $\begin{array}{l}\text { Genel Üretim } \\
\text { Giderleri }\end{array}$ & TOPLAM \\
\hline E.Ü.G.Y. & $77.980,63 €$ & Dizgi & $12.690 €$ & $27.216,76 €$ & 117.887,39€ \\
\hline E.Ü.G.Y. & $96.808,23 €$ & Mekanik & $15.862,5 €$ & $29.461,21 €$ & 142.131,94€ \\
\hline E.Ü.G.Y. & $171.511,54 €$ & Montaj & $13.395 €$ & $21.243,30 €$ & $206.149,84$ € \\
\hline E.Ü.G.Y. & $80.216,51 €$ & & & & $80.216,51 €$ \\
\hline Y.Ü.G.Y. & & Stadyum Montaj & & $55.370,03 €$ & $55.370,03$ € \\
\hline Y.H.G.Y. & & Kalite Kontrol & & $17.463,21 €$ & $17.463,21 €$ \\
\hline Y.H.G.Y. & & Paketleme & & $17.415,21 €$ & $17.415,21 €$ \\
\hline Y.H.G.Y. & & Sevkiyat & & $19.227,21 €$ & $19.227,21 €$ \\
\hline Y.H.G.Y. & & Yemekhane & & $17.070,22 €$ & 17.070,22 € \\
\hline Y.H.G.Y. & & Servis & & $18.790,22$ € & 18.790,22 € \\
\hline Ü.Y.Y.G.Y. & & Üretim Planlama & & $48.272,51 €$ & $48.272,51 €$ \\
\hline Ü.Y.Y.G.Y. & & Teknik Şef & & $27.868,22 €$ & $27.868,22 €$ \\
\hline TOPLAM & $426.516,91 \mathrm{f}$ & & $41.947,50 \mathrm{E}$ & $299.398,10$ E & $767.862,51 \mathrm{E}$ \\
\hline
\end{tabular}

Sipariş maliyet kartının düzenlenmesinden sonra buradan elde edilen sipariş toplam maliyeti bilgisinden yararlanılarak led-line birim maliyeti aşağıdaki şekilde hesaplanmıştır:

$$
\text { Toplam Maliyet }
$$

Led- Line Birim Maliyeti =
Üretilen Led-line Metre
$767.862,51$ き $=83,987324 € /$ Metre

9.142,6 Metre 
İşletmenin Mart, Nisan ve Mayıs 2015 aylarına ait dönem giderleri aşağıdaki tabloda gösterilmiştir.

Tablo 6. Led-Line Üretim İşletmesinin Dönem Giderleri

\begin{tabular}{|l|r|r|r|r|}
\hline \multicolumn{1}{|c|}{ GIDER TÜRÜ } & \multicolumn{1}{c|}{ MART } & \multicolumn{1}{c|}{ NISAN } & \multicolumn{1}{c|}{ MAYIS } & \multicolumn{1}{c|}{ TOPLAM } \\
\hline 750 Ar-ge Giderleri & $24.756,38 €$ & $13.313,71 €$ & $42.982,44 €$ & $81.052,53 €$ \\
\hline 760 Paz.-Satış Dağ. Gid. & $124.575,08 €$ & $49.785,83 €$ & $381.345,92 €$ & $555.756,83 €$ \\
\hline 770 Genel Yönetim Giderleri & $803.062,17 €$ & $485.400,17 €$ & $476.805,31 €$ & $1.765 .267,65 €$ \\
\hline 780 Finansman Giderleri & $231.502,18 €$ & $60.515,54 €$ & $73.462,23 €$ & $365.479,95 €$ \\
\hline TOPLAM & $1.183 .895,81 €$ & $609.015,25 €$ & $974.595,90 €$ & $2.767 .506,96 €$ \\
\hline
\end{tabular}

İşletmede farklı ürünler ve projeler üretildiği için toplam dönem gideri tutarının \% 15'i Stadyum projesinin maliyetine eklenecektir. Aşağıdaki tutarlar Tablo 6'dan alınmıştır.

\begin{tabular}{|c|c|}
\hline $\begin{array}{l}750 \text { Ar-ge Giderleri } \\
760 \text { Paz.-Satıs Dağ. Gid. }\end{array}$ & $\begin{array}{l}=81.052,53 \times 0,15=12.157,88 € \\
=555.756,83 \times 0.15=83.356,02 €\end{array}$ \\
\hline 770 Genel Yönetim Giderleri & $=1.765 .267,65 \times 0,15=264.790,15 €$ \\
\hline 780 Finansman Giderleri & $\begin{aligned}=365.479,95 \times 0,15= & 54.821,99 € \\
\text { TOPLAM } & =415.126,04 €\end{aligned}$ \\
\hline
\end{tabular}

İşletme Stadyum Led-line aydınlatma projesini, 1.017.013 £ + \% 18 KDV olarak satışını gerçekleştirmiştir.

Led-Line üretim işletmesinin sipariş maliyet sistemi kurulmadan önce hesaplanan stadyum projesi gelir ve giderlerine ilişkin bilgiler Tablo 7 'de, sipariş maliyet sisteminin kurulması sonrasında hesaplanan gelir ve giderlere ilişkin bilgiler ise Tablo $8^{\prime}$ de sunulmuştur.

Tablo 7. Stadyum Projesinin Sipariş Maliyet Sistemi Kurulmadan Önce İşletme Tarafından Hesaplanan Gelir ve Giderleri

\begin{tabular}{|c|c|}
\hline GELİRLER & \\
\hline Yurtiçi Hizmet Satışları & $1.017 .013 \mathrm{f}$ \\
\hline TOPLAM & 1.017 .013 \\
\hline \multicolumn{2}{|l|}{ GIDDERLER } \\
\hline Hammadde Malzeme Giderleri & $426.516,91 \mp$ \\
\hline İşçilik Giderleri (Stadyum Montaj Ekibi) & $55.370,03 \mp$ \\
\hline TOPLAM & $481.886,94 \mp$ \\
\hline KAR/ ZARAR & $535.126,06 €$ \\
\hline
\end{tabular}


Tablo 8. Sipariş Maliyet Sistemiyle Hesaplanan Gelir ve Giderler

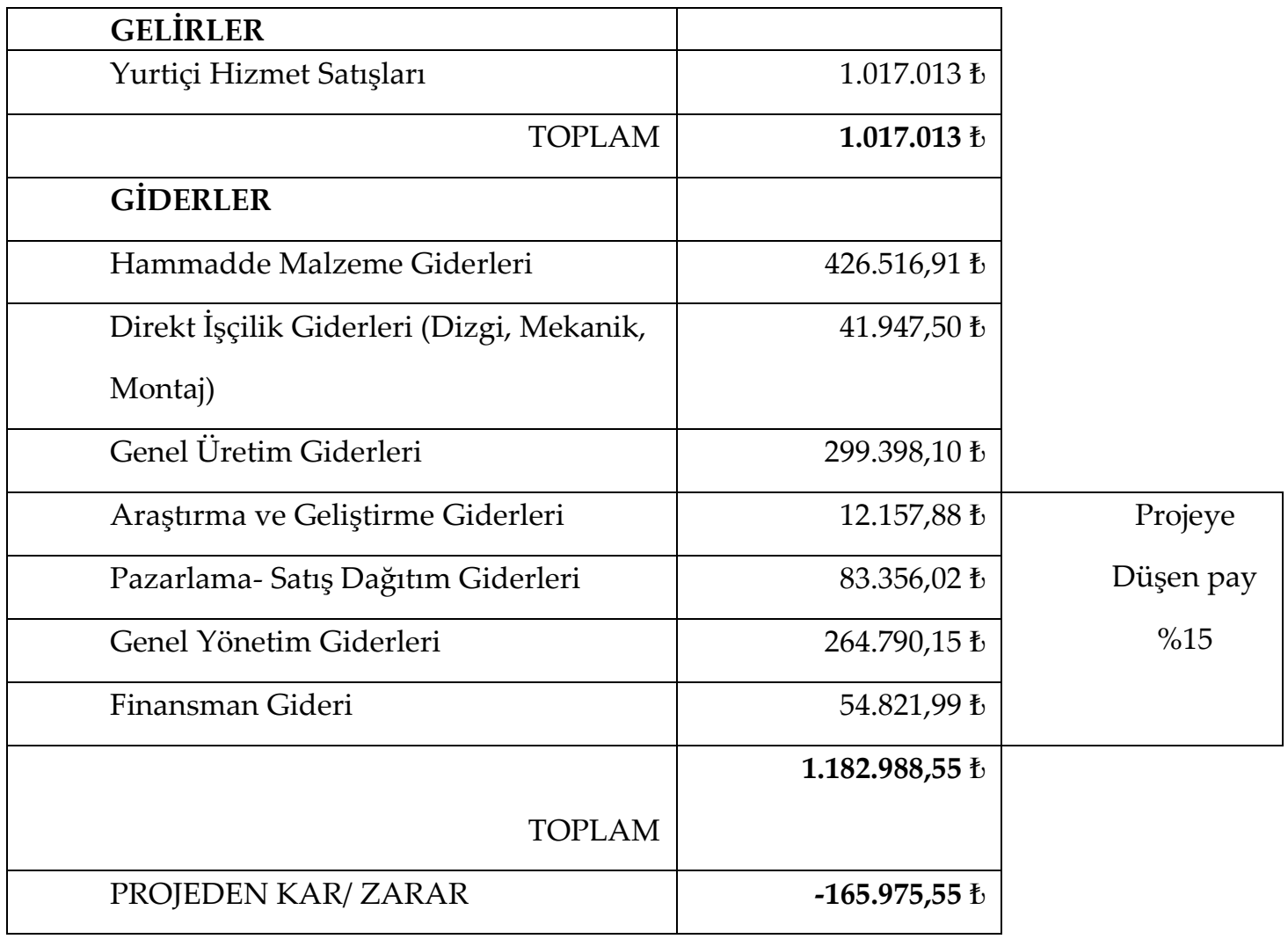

Tablo 7 ve Tablo 8 incelendiğinde sipariş maliyet sistemi kurulmadan önce yapılan hesaplamalarda stadyum projesine genel üretim giderlerinden pay verilmemesinden dolay stadyum projesi karlı gibi görünmesine rağmen, sipariş maliyet sistemi ile yapılan hesaplamalar sonucunda genel üretim giderlerinin de dikkate alınmasıyla aslında projenin zarar ettiği ortaya çıkmıştır.

\section{SONUÇ ve ÖNERILER}

İşletmeler rekabet edebilmek, pazarlardaki yerlerini koruyabilmek ve satış fiyatlarını devam ettirebilmek için daha kaliteli, maliyeti düşük, ucuz ve daha hızlı müşterilerinin isteklerine zamanında cevap verebilmek, teknolojik gelişmeleri izleyerek üretim yapmak zorundadırlar. Üretilen ürünlerin ve sunulan hizmetlerin maliyetlerinin tam olarak hesaplanması işletmeler açısından önemlidir. Etkin bir maliyet muhasebesi sitemi olası aksaklıklara karşı hemen müdahaleyi etkin kılmaktadır.

Uygulamanın gerçekleştirildiği led-line üretim işletmesi üretim yapısı itibariyle sipariş maliyet sistemine kullanılmasına uygun olmakla birlikte, işletmenin maliyet muhasebesi sistemi sipariş maliyeti sisteminin uygulanması için aşağıdaki nedenlerden dolayı yetersiz görülmektedir:

- Siparişlerin maliyetinin hesaplanmasında yaklaşık bir hesaplama yapıllyor olması,

- Siparişin işçilik maliyetlerinin ayrı olarak tutulmaması,

- Genel üretim giderlerinin ve dönem giderlerinin maliyete tam olarak eklenmemesi,

- Stok değerleme yönteminin bulunmaması, 
- Gerekli belge düzenin bulunmaması,

- İşletme yöneticilerinin maliyet muhasebesinin ürettiği bilgiler ve bilgilerin yönetim kararlarında kullanılması konusunda yeterli farkındalığın bulunmaması ve maliyet sistemi kurulmasını gereksiz olarak görmesi,

- Üretim ve maliyet raporlarının her birimde hazırlanıp elektronik kayıt altında tutulmasını sağlayacak kişilerin ya da gerekli bilişim sistemlerinin mevcut olmaması maliyet sisteminin uygulanmasını güçleştirmektedir.

İşletmenin mali yapısı incelendiğinde, proje usulü çalıştığı ve sipariş maliyet yöntemini kısmi olarak uyguladığı, maliyet hesaplarının fiili rakamlar üzerinden hesaplandığı görülmektedir. Ayrıca işletmenin organizasyon yapısında iç kontrol ve maliyet muhasebesi bölümü bulunmamaktadır. İşletmede bilgisayar sistemi kullanılmakta fakat siparişlerin ayrı ayrı maliyet kayıtları yapılmamaktadır.

Stadyum projesinin maliyetinin, önemli bir bölümünü ilk madde ve malzeme giderleri oluşturmaktadır. Yöneticilerden alınan maliyet verilerine göre hesaplamalar yapılmıştır. İşletmede gözlemlenen, yöneticilerin bazı verileri açılamakta imtina gösterdiği net olarak tüm verileri açıklamaktan kaçındığıdır. Maliyetler hesaplanırken, eldeki verilere göre sistem oluşturulmuştur.

İşletmede, maliyetler aylık olarak hesaplanmakta olup ücret sistemi olarak zamana dayalı ücret sistemi uygulanmaktadır. Proje için çalışan işçilerin kayıtları ayrı olarak tutulmamaktadır.

Esas üretim gider yerlerinde biriken giderlerin mamule yüklenmesinde çoğunlukla üretilen mamul miktarı dikkate alınmaktadır.

İşletmenin büyük ve yurt içi ve yurtdışında şubelerinin olması nedeniyle gider çeşitlerinin çokluğu tespit edilmiştir. Muhasebe sisteminde her projenin kaydı kısmi olarak tutulmaktadır. Çünkü sadece hammadde ve malzeme maliyetleri net olarak maliyete yansitılmaktadır. Fakat işçilik giderleri, genel üretim giderleri ve dönem giderleri tam olarak tespit edilmemekte ve siparişlerin maliyetine yüklenmemektedir.

Örnek işletmede, stadyum led-line aydınlatma projesi üretimiyle ilgili bilgiler ilgili kişilerden alınmış ve sipariş maliyet sistemi kurulmaya çalışılmıştır. İşletmenin sipariş maliyet sistemi kurulurken, Esas üretim gider yerleri, yardımcı üretim gider yeri, yardımcı hizmet gider yerleri ve üretim yerleri yönetimi gider yerleri ayrımı yapılıp maliyetleri hesaplanmıştır. İşletmenin mevcut muhasebe sisteminde böyle bir ayrım bulunmamaktadır.

Projenin, sipariş maliyet sisteminde, ilk madde ve malzemelerin tespiti üretim planlama bölümünden alınan iş emirleri ve bilgi işlem bölümünden alınan bilgiler ile ilk madde ve malzeme giderlerinden oluşmaktadır.

İşletme ana üretim merkezi olduğundan bütün üretim faaliyeti buradan yürütülmektedir. İnsan kaynakları bölümü tarafından her ay işçilik giderleri toplu olarak hazırlanmakta fakat her projenin işçilik maliyetleri ayrı olarak kayıt edilmemektedir. Ayrıca, işletmede, işçilik maliyetleri hesaplanırken direkt- endirekt işçilik ayrımının yapılmadığı gözlemlenmiştir. Uygulamada ledline üretiminde çalışan iş̧̧iler belirlenip, personellerin işçi çalışma kartı özetleri oluşturulup direkt, endirekt işçilik maliyetleri hesaplanmaktadır.

Genel üretim giderleri hesaplanırken, işletmenin sadece uygulamaya konu olan Antalya şubesinin giderleri dikkate alınıp ve dönem giderlerinden belli bir pay verilerek projenin maliyetine ilave edilmektedir. İşletme, sipariş maliyeti hesaplarken bu giderleri dikkate almamakta ve projenin maliyetine dahil etmemektedir. 
İşletmenin sipariş maliyet sistemi kurulduktan sonra, proje maliyeti karşılaştırıldığında işletmenin maliyetleri hesaplarken doğru kararlar almadığ 1 ve bunun sonucunda projeden zarar ettiği açıktır.

İşletmeye, maliyetlerini daha doğru hesaplayabilmesi adına aşağıdaki önerilerde bulunulmuştur:

- Maliyet muhasebesi bölümünün oluşturulması,

- İyi bir stok takibi biriminin kurulması ve stok değerleme yöntemlerinin kullanilması,

- Projenin, gider yerlerinin bölümlenmesi ve her bölümün maliyetinin hesaplanması,

İşçilik kayıtlarının her proje içi ayrı olarak tutulması ve direkt-endirekt işçiliklerin tespitinin yapılması,

- Genel üretim giderlerinin uygun bir şekilde bölümler arasında dağıtılması,

- Proje maliyeti hesaplanırken, dönem giderlerinden proje maliyetine belirlenen bir oranda pay verilmesi.

İşletme, önerilen maliyet muhasebesi sistemi ile faaliyetlerini sürdürmesi durumunda, gerçek durumunu daha net görebilecek ve kar veya zarar ettiğini net bir şekilde anlayacaktır. Gereksiz olarak görülen ve oluşturulmayan maliyet muhasebesi bölümünün oluşturulmasının zorunluluğunu görebilecektir.

\section{KAYNAKÇA}

Akdoğan, N. (2009). Tek Düzen Muhasebe Sisteminde Maliyet Muhasebesi Uygulamaları. Ankara: Gazi Kitabevi.

Akpınar, A. ve Atiker, M. (2020). Hazır Beton Sektöründe Sipariş Maliyeti Yöntemi ve Bir Uygulama. Pamukkale Üniversitesi İşletme Araştırmaları Dergisi, 7 (2), 333-361.

Altuğ, O. (2006). Maliyet Muhasebesi. İstanbul: Türkmen Kitabevi.

Blocher, E. J., Chen, K. H., Cokins, G. and Lin, T. W. (2005). Cost Management A Strategic Emphasis, New York: Mc-Graw- Hill Companies.

Büyükmirza, K. (2019). Maliyet ve Yönetim Muhasebesi Tek Düzene Uygun Bir Sistem Yaklaşımı. Ankara: Gazi Kitapevi.

Gürsoy, C. T. (2009). Yönetim ve Maliyet Muhasebesi, İstanbul: Beta Basım Yayım.

Hacırüstemoğlu, R. ve Şakrak, M. (2002). Maliyet Muhasebesinde Güncel Yaklaşımlar, İstanbul: Türkmen Kitabevi.

Hansen D. R. and Mowen, M. M. (2006). Cost Management Accounting and Control, Ohio: ThomsonSouth Western.

Horngren, C. T., Sundem, G. L. and Stratton, W. O. (2002). Introduction to Management Accounting., New Jersey: Pearson Prentice Hall, Upper Saddle River.

Horngren, C. T., Datar, S. M., Foster, G., Rajan, M and Ittner, C. (2009). Cost Accounting A Managerial Emphasis., New Jersey: Pearson Prentice Hall, Upper Saddle River.

Karakaya, M. (2011). Maliyet Muhasebesi. Ankara: Gazi Kitabevi.

Lazol, İ. (2011). Maliyet Muhasebesi. Bursa: Ekin Yayınevi. 
Raiborn, C. A. ve Kinney, M. R. (2011). Cost Accounting Principles, Ohio: South-Western, Cengage Learning.

Yeğinboy, Y. E. ve Yüksel, İ. (2015). Hastane İşletmeleri Kardiyoloji Polikliniğinde Sipariş Maliyet Yöntemiyle Ayaktan Hasta Tanı Maliyetinin Hesaplaması. Dokuz Eylül Üniversitesi Sosyal Bilimler Enstitüsü Dergisi, 17(3), 409-443.

Yereli, A. N., Kayalı, N. ve Demirlioğlu, L. (2015). Karma Maliyet Yöntemi ve Bir Tekstil İşletmesinde Uygulama. Çankırı Karatekin Üniversitesi Sosyal Bilimler Enstitüsü Dergisi, 6(2), 437-464.

Yükçü, S. (2015). UFRS Örnekli ERP Açıklamalı Yönetim Açısından Maliyet Muhasebesi, İzmir: Altın Nokta Yayınevi. 